\title{
MENINGKATKAN KEMAMPUAN BAHASA ANAK DENGAN METODE BERCERITA MENGGUNAKAN BONEKA TANGAN TK NEGERI PEMBINA 1 JAMBI
}

\author{
Sumiati \\ Guru Taman Kanak-Kanak Negeri Pembina 1 Kota Jambi \\ Email: yatitsumiati10@gmail.com
}

\begin{abstract}
Abstrak
Penelitian ini bertujuan untuk mengetahui peningkatan kemampuan berbahasa pada anak melalui metode bercerita dengan boneka tangan. Penelitian ini merupakan penelitian tindakan kelas (PTK). Subjek dalam penelitian ini adalah anak didik kelompok B. Penelitian ini dilakukan di TK Negeri Pembina 1 Jambi. Penelitian ini dilaksanakan dalam empat kali pertemuan dalam dua siklus. Setiap siklus terdiri dari empat tahap yaitu perencanaan, pelaksanaan, observasi, dan refleksi.

Data dikumpulkan melalui metode observasi/catatan lapangan, wawancara, dan dokumentasi. Penelitian ini menggunakan cara triangulasi dengan mencari data dari berbagai sumber data. Hasil dari penelitian ini menunjukkan bahwa ada peningkatan kemampuan berbahasa anak menggunkaan metode ini. Peningkatan kemampuan berbahasa anak dapat dilihat dengan membandingkan hasil observasi yaitu sebelum pelaksanaan sebesar 30\%, setelah siklus I 60\% dan setelah siklus II mencapai $85 \%$.

Berdasarkan hasil penelitian, dapat disimpulkan bahwa melalui metode bercerita dengan gambar seri dapat meningkatkan kemampuan berbahasa pada anak kelompok B TK Negeri Pembina 1 Jambi.
\end{abstract}

\section{Kata Kunci: Bahasa Anak, Metode Bercerita, Boneka Tangan}

\section{A. PENDAHULUAN}

\section{Latar Belakang Masalah}

Pendidikan adalah bagian dari layanan bimbingan kepada anak didik.(Hidayat \& Sumarto, 2018) Pada usia dini anak akan selalu banyak bertanya, memperhatikan, dan membicarakan semua hal yang didengar maupun yang dilihatnya. Ketika akan melihat suatu yang menarik perhatiannya, maka secara spontan anak akan langsung bertanya.

Rasa ingin tahu dan antusias terhadap sesuatu tersebut akan diungkapkan melalui kata-kata atau yang disebut berbicara. Anak usia taman kanak-kanak adalah anak yang berada dalam proses pertumbuhan dan perkembangan yang mempunyai karakteristik yang unik. Salah satu karakteristik yang unik tersebut 
yaitu mempunyai rasa ingin tahu yang besar serta antusias terhadap sesuatu yang ada di sekelilingnya.

Kemampuan anak bisa di bentuk dengan proses layanan pendidikan yang tepat salah satunya dengan verbal. (Sumarto, 2017) Anak yang memiliki kemampuan berbicara telah menunjukkan kematangan dan kesiapan dalam belajar, karena dengan berbicara anak akan mengungkapkan keinginan, minat, perasaan, dan menyampaikan isi hati secara lisan kepada orang lain.

Sebagaimana yang diungkapkan oleh Suhendar (1992:16) : "Berbicara sebagai suatu proses komunikasi, proses perubahan wujud ujaran atau bunyi bahasa yang bermakna, yang disampaikan kepada orang lain.Berbicara merupakan suatu peristiwa penyampaian maksud (ide, pikiran, perasaan) seseorang kepada orang lain dengan menggunakan bahasa lisan (ujaran) sehingga maksud tersebut dapat dipahami orang lain."

Pendapat tersebut diperkuat oleh Endang dan Maliki (2009:36), yang mengatakan bahwa keterampilan verbal dalam berbicara lisan merupakan kemampuan mengekspresikan bahan pembicaraan dalam bahasa kata-kata yang dimengerti banyak orang dan mudah dicerna. Demikian juga, menurut Elizabeth Hurlock (2002:176), bahwa bicara adalah bentuk bahasa yang menggunakan artikulasi atau kata-kata yang digunakan untuk menyampaikan maksud.

Begitu banyak peranan berbicara pada aspek perkembangan anak. Selain berperan pada kemampuan individunya, anak yang memiliki kemampuan berbicara ini pun berpengaruh pada penyesuaian diri dengan lingkungan sebaya, agar dapat diterima sebagai anggota kelompok. Kemampuan berbicara anak juga akan berdampak pula pada kecerdasan. Biasanya anak yang memiliki kecerdasan yang tinggi akan belajar berbicara dengan mudah, cepat memahami pembicaraan orang lain dan mempunyai kosa kata yang lebih banyak.

Namun, kemampuan untuk menguasai keterampilan berbicara ini tidak akan tumbuh dengan sendirinya, tetapi harus melalui proses pembelajaran dan stimulus dari lingkungan terdekat anak. Berbicara erat kaitannya dengan lingkungan sekitar anak, dimulai dari lingkungan keluarga terutama orang tua. Keluarga merupakan lingkungan pertama yang dapat menumbuhkan kemampuan 
berbicara anak, dan merupakan pembelajaran bahasa yang alamiah serta model atau contoh yang pertama ditiru.

Dengan memberikan rangsangan atau stimulus yang tepat, sehingga beberapa aspek perkembangan tersebut dapat berkembang secara optimal. Setiap anak memiliki potensi untuk berbahasa. Potensi kebahasaan itu akan tumbuh dan berkembang, jika fungsi lingkungan diperankan dengan baik. Oleh karena itu, pemerolehan bahasa pertama kali akan terjadi, manakala seorang anak mengenal bahasa di lingkungan keluarga.

Bahasa yang dikenal dan dikuasai oleh anak yang berasal dari keluarga inilah yang menjadi titik awal dalam perkembangan bahasa anak. Tingkat perkembangan bahasa anak ini berbeda-beda sesuai dengan apa yang didengar dan dikenalnya.

Penggunaan bahasa akan berkembang sejalan dengan perkembangan usia anak. Perkembangan bahasa anak dapat dilihat dari kemampuan dalam berbahasa yaitu kemampuan menyimak, kemampuan berbicara, kemampuan membaca, dan kemampuan menulis (Djamarah, 2011: 46). Metode pembelajaran adalah suatu cara atau prosedur yang ditempuh pendidik dalam mengelola pembelajaran yang efektif dan efisien (Susanto, 2011: 120).

Salah satu metode pembelajaran anak usia dini yang dapat digunakan yaitu metode bercerita. Menurut Moeslichatoen (2004: 157) metode bercerita merupakan salah satu pemberian pengalaman belajar bagi anak taman kanakkanak dengan memberikan cerita kepada anak secara lisan. Menurut Dhieni (2005: 6.27) bercerita disertai dengan gambar dapat membantu fantasi dan imajinasi anak karena ada media pendukung yang dapat dilihat secara langsung.

Berdasarkan hasil observasi yang telah dilakukan peneliti di TK Negeri Pembina1 Jambi. yaitu masih banyak anak yang kurang berkembang secara optimal dalam kemampuan berbahasa. Hal ini dapat terjadi dikarenakan metode yang diterapkan guru monoton, guru lebih sering bercerita dengan menggunakan majalah atau lembar kerja anak. Selain itu, guru kurang memberikan kesempatan pada anak untuk menceritakan kembali cerita yang dibawakan oleh guru. 
Melalui interaksi dalam kegiatan belajar maupun bermain, anak secara tidak langsung belajar untuk mengembangkan kemampuan berbicaranya. Hal ini akan terus berlangsung sesuai dengan kemampuan bicara anak seusianya. Sebagaimana yang dikemukakan oleh Isah Cahyani (2004:65), bahwa "Anak belajar berbicara dengan cara berinteraksi dengan lingkungannya, selain itu lingkungan memberikan pelajaran pula terhadap tingkah-laku, ekspresi, dan menambah perbendaharaan kata".

Pendidik atau guru seyogyanya memfasilitasi dengan cara menggunakan model kegiatan yang dapat merangsang minat anak untuk berperan aktif dalam kegiatan pembelajaran. Pendidik atau guru mengidentifikasi dan mengeksplorasi sumber belajar untuk dijadikan media bagi peningkatan keterampilan berbicara anak, dan menciptakan lingkungan belajar yang kondusif, karena guru yang kreatif akan senantiasa mencari pendekatan baru dalam memecahkan masalah, tidak terpaku pada media atau sumber belajar yang monoton, melainkan memilih media pembelajaran yang menarik, bermakna dan menyenangkan sesuai dengan kebutuhan anak.

Sejak masih bayi, seorang manusia telah mulai belajar untuk berkomunikasi dengan orang sekelilingnya. Hal ini terlihat ketika bayi mengungkapkan keinginannya, bayi akan menangis. Ketika menangis, hal ini menunjukkan bahwa bayi tersebut lapar, haus, atau kedinginan. Kemudian bentuk komunikasi bayi diteruskan melalui bahasa isyarat, celotehan, dan ekspresi emosional. Sulit diketahui sejak kapan bayi memulai untuk belajar berbicara, namun berawal dari celotehan bayi memulai belajar berbicara.

Seiring dengan bertambahnya usia anak, dapat mengucapkan beberapa kata, pada usia dua tahun kosa kata anak lebih dari 1.500 buah dan kemampuan berbicaranya akan berkembang pesat ketika anak memasuki taman kanak-kanak, hasrat anak untuk mempelajari kata-kata baru sangat kuat dan tentunya melalui stimulasi dari lingkungan taman kanak kanak. Taman kanak-kanak dianggap sebagai tempat yang tepat bagi anak untuk menumbuhkan kemampuan berbahasa anak. 
Perkembangan bahasa anak TK terlihat dari minat yang tinggi pada hurufhuruf dan angka-angka, sudah dapat mengingat kembali pengertian berdasarkan kata-kata, kosa kata anak lebih dari 2.500. Dan, program pengembangan keterampilan berbicara di taman kanak-kanak banyak memberi kesempatan anak untuk berbicara, menceritakan pengalamannya secara sederhana. Anak dibiasakan untuk bertanya, menjawab pertanyaan, dan mengekspresikan keinginannya.

Sesuai dengan tujuan pengembangan berbahasa anak TK, menurut Soemantri (Hartini: 2005), yaitu agar anak mampu mengungkapkan melalui bahasa yang sederhana secara tepat, mampu berkomunikasi secara efektif dengan lingkungan dan membangkitkan minat untuk dapat berbahasa Indonesia dengan baik.

Kenyataannya pengembangan keterampilan berbicara anak di taman kanak-kanak belum maksimal dan cenderung mendapat hambatan. Tidak semua anak mampu menguasai keterampilan berbicara. Ketidakmampuan anak berkomunikasi secara lisan ini dikarenakan beberapa alasan, salah satu alasan tersebut, yaitu kegiatan pembelajaran yang kurang memperhatikan aspek aspek perkembangan anak.

Menurut Suhartono (2005:143), kegiatan pengembangan berbicara anak pada umumnya dilakukan dalam bentuk interaksi belajar mengajar. Kegiatan itu dapat berjalan dengan baik jika didukung oleh adanya media atau sarana prasarana. Media pembelajaran berfungsi sebagai alat yang menarik perhatian dan untuk menumbuhkan minat anak berperan serta dalam proses pembelajaran dan media pembelajaran juga berfungsi sebagai alat untuk menghindari verbalisme. Salah satu media pembelajaran yang digunakan pada penelitian ini adalah menggunakan media Boneka Tangan. Boneka Tangan adalah media yang sangat akrab dengan dunia bermain anak.

Dengan melalui Boneka Tangan diharapkan anak akan lebih tertarik untuk mencoba menggunakan dan senang memainkannya secara langsung dengan jarijari tangannya. Boneka Tangan tangan sangat populer bagi dunia bermain anak. Dengan menggunakan media Boneka Tangan diharapkan akan meningkatkan minat anak untuk berpartisipasi dalam proses pembelajaran. 
Pada kenyataannya di Taman Kanak-Kanak Negeri Pembina1, keterampilan bahasa anak masih sangat rendah hal tersebut dapat dilihat dari tingkat keaktifan anak dalam berbicara, baik dengan sesama teman maupun dengan guru. Permasalahan tersebut muncul kemungkinan dikarenakan pengetahuan guru dalam strategi pembelajaran untuk meningkatkan keterampilan bahasa anak, agar anak dapat terangsang untuk lebih meningkatkan keterampilannya.

Dalam rangka mengembangkan persoalan tersebut melalui penelitian tentang bagaimana meningkatkan keterampilan bahasa anak Taman Kanak-Kanak melalui penggunakan media Boneka Tangan tangan, yang penulis rumuskan dalam judul penelitian, "Meningkatkan keterampilan bahasa anak dengan metode bercerita menggunakan media Boneka Tangan di Taman Kanak kanak negeri Pembina 1 Jambi".

\section{Rumusan Masalah}

a. Bagaimana penerapan metode bercerita dengan media Boneka Tangan di Taman Kanak kanak Negeri Pembina 1 Jambi?

b. Bagaimana tingkat keterampilan berbahasa anak di Taman Kanak-Kanak Negeri Pembina 1 Jambi?

c. Apakah terdapat peningkatan keterampilan bahasa anak di Taman KanakKanak Negeri Pembina 1 Jambi setelah dibelajarkan dengan menggunakan metode bercerita menggunakan media Boneka Tangan?

\section{Tujuan Penelitian}

a. Untuk mengetahui penerapan metode bercerita dengan media Boneka Tangan di Taman Kanak-Kanak Negeri Pembina 1 Jambi.

b. Untuk mengetahui tingkat kemampuan berbahasa anak di Taman KanakKanakNegeri Pembina 1 Jambi.

c. Untuk mengetahui peningkatan keterampilan bahasa anak di Taman Kanak-KanakNegeri Pembina 1 Jambi. 


\section{Manfaat Penelitian}

- Bagi guru

Guru lebih mudah mengajarkan keterampilan bahasa anak, karena memakai media yang menarik, menyenangkan, dan bermakna bagi anak. Memotivasi peranan guru dalam meningkatkan kemampuan berbicara anak untuk menciptakan media yang menarik, menyenangkan, dan bermakna agar anak banyak terlibat dalam kegiatan aktivitas berbicara.

- Bagi lembaga pendidikan

Hasil penelitian diharapkan maenjadi sumbangsih kepada seluruh lembaga pendidikan pada umumnya, dan khususnya bagi TK Negeri Pembina 1 Jambi dalam rangka meningkatkan kualitas belajar, terutama keterampilan bahasa anak taman kanak-kanak.

- Bagi orang tua

Penelitian ini diharapkan menjadi alternatif dalam meningkatkan keterampilan berbicara sebagai bahan bacaan dan pengetahuan yang dapat diterapkan dalam kehidupan sehari hari.

- Bagi peneliti selanjutnya

Dapat dijadikan sebagai acuan untuk kajian pendidikan selanjutnya dan menjadi inspirasi serta motivasi bagi kemajuan pengembangan pendidikan bagi anak usia dini.

\section{B. LANDASAN TEORI}

\section{Metode Bercerita}

Dalam pelaksanaan kegiatan pembelajaran di PAUD metode bercerita dilaksanakan dalam upaya memperkenalkan, memberi keterangan, atau penjelasan tentang hal baru dalam rangka menyampaikan pembelajaran yang dapat mengembangkan berbagai aspek pada anak.

Menurut Fadlillah (2012:172), metode bercerita ialah metode yang mengisahkan suatu peristiwa atau kejadian kepada peserta didik. Kejadian atau peristiwa tersebut disampaikan melalui tutur kata, ungkapan dan mimik wajah yang unik. Metode bercerita berarti penyampaian cerita dengan cara bertutur yang 
membedakan antara bercerita dengan metode penyampaian cerita lain adalah lebih menonjol aspek teknis penceritaan lainnya.

Berdasarkan hal tersebut maka disimpulkan bahwa metode bercerita adalah salah satu strategi pembelajaran dimana penyampaiannya melalui tutur kata secara lisan dengan menceritakan kisah atau suatu peristiwa dan informasi tanpa meninggalkan tujuan dari pembelajaran tersebut.

Pendapat diatas menegaskan bahwa metode bercerita dapat membantu mengoptimalkan kemampuan mengungkapkan bahasa, dengan menambah perbendaharaan kosa kata, kemampuan mengucapkan kata-kata, melatih merangkai kalimat sesuai tahap perkembangannya, dan selanjutnya anak dapat mengekspresikan dirinya.

\section{Boneka Tangan}

Boneka adalah media yang sangat akrab dengan dunia bermain anak. Menurut Gallahue (Cahaya, S.I : 2007), bermain adalah suatu aktivitas langsung dan spontan di mana seorang anak menggunakan orang lain atau benda-benda di sekitarnya dengan senang, sukarela, dan dengan imajinatif, menggunakan perasaannya, tangannya, atau seluruh anggota tubuhnya. Dengan melalui penggunakan media boneka tangan secara tidak langsung anak akan belajar mengenai keterampilan berbicara tanpa disadari.

Dengan melalui boneka tangan diharapkan anak akan lebih tertarik untuk mencoba menggunakan dan senang memainkannya secara langsung dengan jarijari tangannya. Boneka tangan sangat populer bagi dunia bermain anak, seperti yang ditampilkan di media elektronik, yaitu boneka si unyil pada acara "Laptop si Unyil".

Untuk keperluan sekolah dapat dibuat Boneka Tangan yang disesuaikan dengan cerita-cerita jaman sekarang. Untuk tiap daerah pembuatan Boneka Tangan ini disesuaikan dengan keadaan daerah masing-masing. 


\section{METODE PENELITIAN}

\section{Pendekatan Penelitian}

Penelitian ini menggunakan metode PTK. PTK merupakan salah satu upaya guru atau praktisi dalam bentuk berbagai kegiatan yang dilakukan untuk memperbaiki keadaan yang tidak atau kurang memuaskan dan atau untuk meningkatkan mutu pembelajaran di kelas. PTK merupakan kegiatan yang langsung berhubungan dengan tugas guru atau praktisi di lapangan. Singkatnya PTK merupakan penelitian praktis yang bertujuan untuk memperbaiki praktik pembelajaran yang ada.

\section{Prosedur Penelitian}

Model siklus yang digunakan dalam penelitian ini adalah model yang dikembangkan Arikunto (2008:3) yang terdiri dari:

1) perencanaan (planning),

2) tindakan (acting),

3) pengamatan (observing),

4) refleksi (reflecting). Hubungan keempat komponen itu dipandang sebagai satu siklus.

\section{Lokasi dan Waktu Penelitian}

Penelitian ini dilaksanakan di Taman Kanak-Kanak Negeri Pembina 1 Jambi pada tahun ajaran 2016/2017 pada bulan Februari 2016 dengan alasan untuk memudahkan penelitian karena peneliti adalah pendidik di TK tersebut.

\section{Subjek Penelitian}

Subjek penelitian ini adalah siswa Taman Kanak-Kanak Negeri Pembina 1 Jambi pada tahun ajaran 2016/2017 dengan jumlah murid 15 anak.

\section{Teknik Pengumpulan Data}

- Metode Observasi 
Observasi dilakukan oleh peneliti selama proses pembelajaran dengan menggunakan media kartu angka dalam peningkatan kognitif anak usia dini pada pembelajaran tersebut.

- Metode Wawancara

Denzim (Goetz dan LeCompte, 1984) dalam Rochiati Wiriaatmadja (2005: 117) menjelaskan bahwa wawancara merupakan pertanyaan-pertanyaan yang diajukan secara verbal kepada orang-orang yang dianggap dapat memberikan informasi atau penjelasan hal-hal yang dipandang perlu.

- Dokumentasi

Dokumen yang digunakan berupa daftar kelompok siswa, daftar nilai siswa, dan foto kegiatan pembelajaran. Dokumentasi foto untuk memberikan gambaran secara lebih nyata mengenai kegiatan kelompok siswa dan menggambarkan suasanan kelas ketika aktivitas belajar berlangsung.

\section{HASIL PENELITIAN DAN PEMBAHASAN}

\section{Lokasi Penelitian}

Penelitian dilakukan di TK Negeri Pembina1 Jambi yang mempunyai mempunyai 6 ruang kelas. Subjek penelitian dalam penelitian ini adalah anak kelompok yang terdiri dari 15 anak.

\section{Hasil Penelitian}

Kemampuan berbahasa Anak Setelah Tindakan Hasil penelitian ini akan diuraikan berdasarkan urutan siklus, yaitu :

a. Tindakan Siklus I

Hasil penelitian pada Siklus 1 akan diuraikan berdasarkan pada tiga komponen, yaitu:

a. Perencanaan,

b. Tindakan dan pengamatan

c. Refleksi.

Perencanaan Tindakan Siklus I dilaksanakan dalam 3 kali pertemuan. Dalam tahap tindakan Siklus I peneliti dan teman sejawat melakukan kegiatan yaitu: 
1) Menyusun Rencana Kegiatan Harian Rencana pelaksanaan pembelajaran disusun oleh peneliti dalam Rencana Kegiatan Harian (RKH). Berdasarkan kesepakatan yang telah ditentukan sebelumnya, peneliti dan teman sejawat memberikan kegiatan menggunakan gambar seri pada kegiatan inti.

2) Menyiapkan lembar Observasi Lembar observasi digunakan untuk mencatat hasil pengamatan selama penelitian berlangsung. Kemampuan berbahsa, menerima bahasa, menyampaikan bahasa anak ditentukan dengan skor yaitu skor 3 untuk anak yang berkembang dengan baik, skor 2 untuk anak yang berkembang cukup, dan skor 1 untuk anak yang kurang.

Siklus I pertemuan pertama dilaksanakan pada minggu pertama 2Januari 2017. Pelaksanaan siklus I pertemuan pertama meliputi 3 kegiatan yaitu kegiatan awal, kegiatan inti, dan kegiatan akhir.

Siklus I pertemuan kedua dilaksanakan pada Minggu kedua 9 Januari 2017. Pelaksanaan siklus I pertemuan kedua meliputi 3 kegiatan yaitu kegiatan awal, kegiatan inti, dan kegiatan akhir.

b. Kegiatan Siklus II

a. Perencanaan

Tindakan Siklus II dilaksanakan dalam 3 kali pertemuan. Dalam tahap tindakan Siklus II peneliti dan teman sejawat melakukan kegiatan yaitu:

1) Menyusun Rencana Kegiatan Harian Rencana pelaksanaan pembelajaran disusun oleh peneliti dalam Rencana Kegiatan Harian (RKH). Berdasarkan kesepakatan yang telah ditentukan sebelumnya, peneliti dan teman sejawat memberikan kegiatan menggunakan gambar seri pada kegiatan inti.

2) Menyiapkan lembar Observasi Lembar observasi digunakan untuk mencatat hasil pengamatan selama penelitian berlangsung. Kemampuan berbahsa, menerima bahasa, menyampaikan bahasa anak ditentukan dengan skor yaitu skor 3 untuk anak yang berkembang dengan baik, skor 2 untuk anak yang berkembang cukup, dan skor 1 untuk anak yang kurang. 
Siklus II pertemuan pertama dilaksanakan pada minggu pertama 23 Januari 2017 dengan tema Pelaksanaan siklus I pertemuan pertama meliputi 3 kegiatan yaitu kegiatan awal, kegiatan inti, dan kegiatan akhir.

a) Kegiatan Awal Kegiatan awal dimulai dengan aktifitas outdoor yaitu dengan aktivitas fisik berupa kegiatn senam bersama, kemudian berbaris dan masuk ruang kelas secara teratur. Setelah masuk di dalam kelas, anak diposisikan duduk melingkar untuk kegiatan pembukaan yaitu salam, berdoa dan apersepsi tentang kegiatan bercerita menggunakan gambar seri.

b) Kegiatan Inti Pada kegiatan inti anak diminta untuk melaksanakan tugas sesuai aturan yang sudah disepakati bersama. Karena masih tahap awal, anak masih membutuhkan banyak bimbingan

Siklus II pertemuan kedua dilaksanakan pada Minggu kedua 2018. Pelaksanaan siklus II pertemuan kedua meliputi 3 kegiatan yaitu kegiatan awal, kegiatan inti, dan kegiatan akhir.

Siklus II pertemuan ketiga dilaksanakan pada Minggu ketiga bulan Agustus. Pelaksanaan siklus II pertemuan kedua meliputi 3 kegiatan yaitu kegiatan awal, kegiatan inti, dan kegiatan akhir.

Siklus III pertemuan ketiga dilaksanakan pada Minggu ketiga bulan September 2018. Pelaksanaan siklus III pertemuan kedua meliputi 3 kegiatan yaitu kegiatan awal, kegiatan inti, dan kegiatan akhir.

\section{c. Pembahasan}

Kemampuan berbahasa anak dapat dilakukan dengan berbagai cara, salah satunya adalah dengan bercerita menggunakan boneka tangan. Bercerita menggunakan boneka tangan dalam penelitian ini adalah media yang dari boneka berbagai bentuk, yang masing-masing boneka mempunya bentuk warna yang menarik.

Bermain dengan boneka tangan. anak dapat bercerita dengan mengenal bentuk dan bunyi huruf atau bahkan dapat menyebutkan kata yang tercantum di dalam cerita tersebut. Dari hasil penelitian tindakan kelas yang dilakukan selama 3 siklus yang terdiri dari 9 kali pertemuan, aspek kemampuan berbahasa anak 
mengalami peningkatan dari kondisi awal sebelum diadakan penelitian tindakan kelas hingga penelitian tindakan.

Peningkatan perkembangan kemampuan berbahasa anak kelompok B di TK Negeri Pembina1 Jambijika dipersentase rata-rata dari kondisi awal 29,2\%, dan mencapai 83,3\% setelah dilakukan tindakan atau dari 7 anak menjadi 13 anak.

Hasil penelitian menunjukkan bahwa kemampuan berbahasa dapat ditingkatkan menggunakan kegiatan bercerita dengan menggunakan boneka tangan berbagai karakter. dalam penelitian ini sebagai alat peraga yang sangat membantu guru.

Hal ini sejalan dengan pendapat Andang Ismail bahwa dengan bantuan alat peraga, guru bukan saja dapat menjelaskan lebih banyak hal dalam waktu yang lebih singkat, juga dapat mencapai hasil yang lebih cepat, (Andang Ismail, 2006: 181). Dengan bantuan boneka tangan, maka anak diharapkan dapat mengenal kata dengan cepat dengan cara yang menyenangkan.

Lebih lanjut Rose dan Roe menjelaskan dalam pembelajaran membaca permulaan guru dapat menggunakan strategi bermain dengan media bercerita dengan boneka tangan. tersebut digunakan sebagai media dalam permainan. Selain itu, Mackey (dalam Ahmad Rofi'uddin, 2003: 44) berpendapat bahwa dalam pembelajaran membaca teknis guru dapat menggunakan strategi permainan membaca, misalnya: cocokkan kartu, ucapkan kata itu, temukan kata itu, kontes ucapan, temukan kalimat itu, baca dan berbuat dan sebagainya.

Berdasarkan teori-teori yang telah dikemukakan, peneliti menyimpulkan bahwa kemampuan berbahasa dapat ditingkatkan melalui kegiatan bercerita dengan menggunakan gambar seri. Melalui gambar seri, selain anak mampu membaca juga mampu menyimak dan menyampaikan kembali isi cerita Selain itu, bercerita dengan boneka tangan akan lebih efektif jika dibandingkan dengan bercerita tanpa media. 


\section{E. KESIMPULAN DAN SARAN}

\section{Kesimpulan}

Berdasarkan hasil penelitian dan pembahasan dalam penelitian ini dapat disimpulkan bahwa kemampuan berbahasa khususnya menyimak dan menceritakan kembali isi cerita pada anak kelompok B di TK Negeri Pembina 1 Jambi dapat ditingkatkan menggunakan media boneka tangan dalam proses pembelajaran cara masing-masing anak membawa/memegang boneka sesuai karakternya. secara langsung.

Hasil penelitian menunjukkan bahwa ada peningkatan kemampuan berbahasa yaitu pada kondisi awal sebesar 29,2\%, meningkat pada Siklus I menjadi 58,3\%, dan Siklus II meningkat menjadi 63,3\%. Dan pada siklus III meningkat menjadi 83,5\%. Hal ini menunjukkan bahwa anak-anak di TK Negeri Pembina 1 Jambi telah mencapai kemampuan mengenal huruf pada kriteria baik seperti yang diharapkan. Pembelajaran dalam meningkatkan kemampuan mengenal kata dikatakan berhasil, karena dari 15 anak yang sudah mencapai pada kriteria baik sebanyak 13 anak ( $83.5 \%)$.

\section{B. Saran}

Berdasarkan hasil penelitian dan kesimpulan di atas, peneliti memberikan saran berikut ini :

\section{Bagi Orangtua}

Bagi orang tua Disarankan agar sering bercerita dengan menggunakan media boneka tangan dan media lainnya dalam mengenalkan dan meningkatkan kemampuan berbahasa sejak dini agar anak dapat bereksplorasi, menambah pengalaman, dan wawasan baru untuk meningkatkan kemampuan persiapan membaca untuk melnjutkan ke pendidikan lebih lanjut .

\section{Bagi Guru TK}

Disarankan bagi guru agar dapat menggunakan media boneka tangan dalam proses kegiatan belajar mengajar untuk meningkatkan kemampuan berbahasa.

3 Bagi Kepala Sekolah 
Kepala sekolah perlu memfasilitasi media pembelajaran seperti buku-buku bacaan sesuai dengan jumlah kelas dan tiap kelas minimal 4 set untuk mempermudah guru dalam memberikan pemahaman dalam aspek bahasa juga mempermudah anak kelompok B dalam persiapan membaca.

4. Bagi peneliti lain

Bagi peneliti lain agar dapat meneliti dengan berbagai media dengan bentuk dan ukuran yang lebih bervariasi dalam meningkatkan kemampuan berbahasa maupun meningkatkan kemampuan lainnya seperti: kemampuan berbicara dan kemampuan membaca awal anak.

\section{DAFTAR PUSTAKA}

Arikunto Suharsimi, dkk. 2017. Penelitian Tindakan Kelas Edisi Revisi. Jakarta:

Bumi Aksara. Dhieni, Nurbiana dkk. 2005. Metode Pengembangan Bahasa. Jakarta: Universitas Terbuka.

Djamarah Syaiful Bahri. 2011. Psikologi Belajar. Jakarta: PT Rineka Cipta.

Kunandar. 2008. Langkah Mudah Penelitian Tindakan Kelas Sebagai Pengembangan Profesi Guru. Jakarta : PT. Raja Grafindo Persada.

Moeslichatoen. 2004. Metode Pengajaran Di Taman Kanak-Kanak. Jakarta: PT Rineka Cipta.

Permendikbud. 2014. Standar Nasional Pendidikan Anak Usia Dini. Jakarta:

Permendikbud. Sugiyono. 2014. Metode Penelitian Kuantitatif Kualitatif dan $R \& D$. Bandung: Alfabeta.

Susanto Ahmad. 2017. Pendidikan Anak Usia Dini (Konsep dan Teori). Jakarta: Bumi Aksara.

Widiyanto, Joko. 2016. SPSS For Windows Untuk Analisis Data Statistik Dan Penelitian Untuk Analisis Data Statistik dan Penelitian. Surakarta: FKIP Universitas Muhammadiyah Surakarta.

Rika Ariyani, Editor Jurnal Literasiologi. Literasi Kita Indonesia. STAI Syekh Maulana Qori. Merangin Bangko.

Hidayat, H., \& Sumarto, S. (2018). Urgensi Pembukaan Unit Layanan Pendidikan Bimbingan dan Konseling (BK) di Setiap Program Studi Fakultas Ilmu Tarbiyah dan Pendidikan UIN Sulthan Thaha Saifuddin Jambi. Jurnal AlAshlah, 2(2). Diambil dari https://journal.staimaarif jambi.ac.id/index.php/alashlahjournal/article/view/141 
Sumarto. (2017). PENGEMBANGAN MODEL LAYANAN KONSULTASI DALAM SETTING SEKOLAH. Jurnal An-Nahdhah, 9(1). Diambil dari https://journal.staimaarif-jambi.ac.id/index.php/annahdhah/article/view/12 